
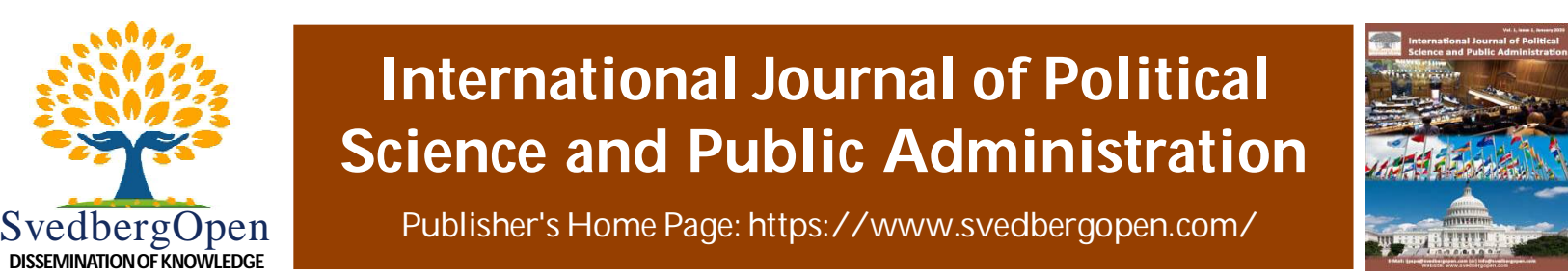

Research Paper

Open A ccess

\title{
Economic contributions of fisherwomen in Pulicat lake for public policy considerations
}

\author{
B. Madhana Rekha ${ }^{1 *}$
}

'Madras Christian College, (Autonomous), East Tambaram, Chennai 600059, Tamil Nadu, India. E-mail: madhanarekha@mcc.edu.in

\section{Article Info}

Volume 1, Issue 1, June 2021

Received : 01 December 2020

Accepted : 17 April 2021

Published : 05 June 2021

doi: 10.51483/IJPSPA.1.1.2021.31-35

\begin{abstract}
Women play a significant role in the fishery sector. They financially support their families and manage their domestic responsibilities at home. The present research paper focuses on the everyday struggles faced by fisherwomen of Pulicat lake in Tamil Nadu. The findings of the study reveals that there is a huge increase in export of aquaculture products. While the fishermen catch fishes in the deep sea, fisherwomen ensure that it is preserved and sold properly. The study proves that fisherwomen of Pulicat Lake are being exploited by the middlemen and commission agents who took commissions. It is unfortunate that the economic contributions of fisherwomen are not recognized in the Gross Domestic Product of India. The researcher recommends that the government of Tamil Nadu should eradicate the interference of middlemen and recognize the economic contributions made by fisherwomen in the national economy of India.
\end{abstract}

Keywords: Exploitation, Fisherwomen, Pulicat, Middlemen, Commission agents

(C) 2021 International Journal of Political Science and Public Administration. This is an open access article under the CC BY license (https://creativecommons.org/licenses/by/4.0/), which permits unrestricted use, distribution, and reproduction in any medium, provided you give appropriate credit to the original author(s) and the source, provide a link to the Creative Commons license, and indicate if changes were made.

\section{Introduction}

India has a coastline of 8,129 km with 3,638 fishing villages (Vijaya Khader, 2008). The fisheries sector has grown and increased the national income, exports, food and nutritional security leading to employment generation in the country. The present research paper was undertaken with the financial assistance from the University Grants Commission to study the Economic Contributions of Fisher Women in Pulicat Lake during 2018-2020. Earlier study reveals that fisheries sector have been contributing to the economic growth of the nation and nearly six million people are dependent on fisheries for their livelihood in India (Amita Saxena, 2011).

Tamil Nadu possesses about 3.83 lakh hectare of inland water resources of which the brackish water area is 56,000 hectare. It supports the livelihood of 10.07 lakh marine fishers through 5,893 mechanized boats and 38,779 traditional fishing crafts. The inland fisher population in 2017-2018 was 2,30 lakhs. There are about 270 inland fishermen cooperative societies with 59,000 registered active members. The total fish production in 2017-2018 was 7.12 lakh tons and the Tamil Nadu state could export 88.257 metric tons of marine products. It stood fourth in the country and earned a foreign exchange of Rs. 4,341.78 cr during 2016-2017. The state government report shows that about $48.8 \%$ of the fishers in Tamil Nadu are women. There are 460 fisheries co-operatives with 250,276 women as members which indicates a high level of women participation. Government of Tamil Nadu Report: Fisheries at a Glance (2016-2017).

\footnotetext{
* Corresponding author: B Madhana Rekha, Madras Christian College, (Autonomous), East Tambaram, Chennai 600059, Tamil Nadu, India. E-mail: madhanarekha@mcc.edu.in
} 


\section{Aim and objectives of the research study}

A minor research project funded by the University Grants Commission was undertaken to study the Economic Contributions of fisherwomen in the Pulicat lake of the Tiruvallur district in Tamil Nadu, South India with the following objectives:

1. To examine the role of fishing sector in the development of fisherwomen in Tamil Nadu in the Indian context.

2. To portray the socioeconomic conditions of fisherwomen living in the Pulicat village.

3. To study the income, educational qualification, work participation between male and female, ownership pattern of productive assets in the fisher community.

4. To explain the factors determining the economic status and living conditions of the local people.

5. To assess the effectiveness of government policies and programs in ameliorating the socio economic conditions of fishers with special emphasis on 'women'.

6. To point out the findings of the study and to suggest the fisher community the measures advisable for specific alternative strategy for the development of fishers.

\section{Materials and methods}

The primary source for research have been designed to collect with the help of interview schedule and a structured questionnaire with regard to size of the family, occupation, income, land holdings, education, living conditions, health status and social status. Secondary sources of data have been collected from the published books, journals and government reports. A qualitative research study was undertaken by selecting 500 samples through simple random sampling technique using lottery method to study the 52 villages in Pulicat. Focus group discussions were conducted to know the opinion of the fishers. Interview method and observation techniques were adopted by the researcher to understand the facts of the selected village. An interactive session was held with the native leaders who arranged meetings to meet the people. The frequency analysis of the questionnaire samples were done and interpreted to infer the important findings with the help of statistician. The study was videographed and prepared as a documentary on Pulicat by the principal investigator. The final data interpretation was interpreted as data visualization with the help of software experts. The researcher was able to conduct awareness programs to the fisherwomen of Pulicat to educate them on the policies and programs for women.

\section{Results and discussion}

The research study was undertaken to find out the economic contributions of fisherwomen in Pulicat of Thiruvallur district of Tamil Nadu, India. About 500 structured questionnaire schedule were distributed out of which 499 samples were returned and one was not returned by the fisherwomen. The researcher adopted simple random sampling technique through lottery method to collect samples from 52 villages of Pulicat. The opinions of the respondents are given as percentage.

\section{Awareness of government policies}

The research study reveals that $92.99 \%$ of the fisherwomen are aware of the Marine Fishing Policy.

About $94.79 \%$ of the respondents agreed that Government of India should ban Indian Fisherman from Fishing in Other Countries' Waters. Nearly $97.39 \%$ of the respondents expected that the Indian government should provide more facilities to fishers considering the risks involved in their profession. Almost $98.20 \%$ of the respondents were aware of the advantages of having vessel monitoring systems on board. About $96.79 \%$ of the fishers are willing to fit the Vessel Monitoring System In their vessel with government subsidy. Almost 97.39\% of them agreed that the government had alerted and evacuated people during disasters and natural calamities. The study proved that $98.00 \%$ of the fishers agreed to the Vessel registration and licensing policy.

However, only $0.60 \%$ were satisfied with the government welfare policies to the Fishermen Communities. Nearly $98.40 \%$ expressed that government should provide modern storage facilities. Very few fishers $0.40 \%$ people were satisfied with the Insurance coverage schemes. Majority were not satisfied. None of the respondents were satisfied with the Monetary Compensation given by the government for ban period. Nearly $98.40 \%$ felt that effective mariculture was needed for the fishers. They expressed that government should formulate more effective policies to help the growth of mariculture farming. 


\section{The post-harvest facilities}

The study revealed that none of the respondents were satisfied with hygiene standards of storage facilities available. About $2.40 \%$ felt that they are paid less for the goods supplied. All the respondents agreed that the middle men were exploiting fishers by paying less for their yield supplied by them. All of them agreed that export of Indian fish products provided maximum profits than the retail selling in local markets. About $98.40 \%$ of them agreed that small fishes were also being utilized without wastage. Nearly $98.00 \%$ of the respondents were satisfied with the provision to prevent loss of yield or catches. Almost $99.20 \%$ of the respondents agreed that Indian fish products should improve quality to attract International markets. All the respondents agreed that there was a growing decline in the yield or catches. Few of them about $14.23 \%$ were interested in joining fishing industry. Only $14.03 \%$ of them were unable to market their goods without wastage. All the respondents felt that government need not reduce the ban period of fishing but the compensation paid by the government for the ban period is not sufficient and it should be increased to manage their livelihood.

\section{Awareness on environmental pollution}

The research study shows that almost $98.80 \%$ agreed that fishery resources are exhaustive. About $99.20 \%$ agreed that there is depletion of marine resources. All the respondents agreed that uncontrollable harvest will exhaust marine resources. Almost $99.20 \%$ agreed that the pollution of marine waters are due to dumping of waste into the seas. All of them agreed that there are sufficient steps taken for protection of maritime industry and the growing of mangroves will help prevent flooding into residential areas of coastal villages. All of them accepted that developing artificial coral reef helps in improving the catches. All the respondents agreed that developing hatcheries is helpful for increasing the yield in catches. Everyone were aware of the effects of marine pollution.

It is observed from the research study that both central and state governments provided several programs for the uplift of fishers. The department of fisheries provided subsidy for boats, houses, welfare schemes for the childrens' education and loans through cooperative societies. Members of the cooperative societies were entitled to get several subsidies to purchase geographical positioning systems to monitor their vessels which alerts the fishers while venturing the sea especially in rough unpredictable climatic conditions. The respondents expressed that many lives were protected due to the monitoring equipments which the fishermen had installed in their boats. The study revealed that majority of the respondents about $70 \%$ of them had attended various types of job training programs organized by the NGOs. Women expressed that they lacked space to start their own businesses. All the respondents agreed that restriction in usage of mechanized boats, hooks, gears, mesh and reducing the size of the boat will help in sustainable development of the environment. They accepted that the marine resources were depleting due to the marine pollution. They strongly believed that steps must be taken to punish those who are dumping of plastics, industrial hazardous waste, sewage waste, human waste, oil spillage into the sea. All the respondents agreed that growing of mangroves will prevent flooding into residential areas. All the respondents felt that growing of artificial coral reefs would help in improving the yield in catches. Similarly developing hatcheries will be helpful to increase the yield. Majority of the respondents expressed that their confidence level had improved through the various kinds of training programs they offered by the government and non-governmental organizations. Almost all the respondents said that the government is unable to improve their standard of living.

\section{Conclusion}

From the research study it can be concluded that the low educational attainment and sociocultural constraints hamper the full participation of women in development activities of the fisheries sector. Their ability to use and access the available information was affected due to poverty and illiteracy. They lacked competence and self-confidence in availing the government schemes and projects offered for the welfare of fishers. The remarkable functioning of NGOs in training the fisherwomen has improved their self confidence level but unfortunately the fishers were unable to come out of the clutches of poverty stricken socio economic conditions. The participation of women before and after fish capture has been given less importance by the government, leading to the invisibility of women as economic contributors to the fishery sector. In reality women are seen working in both pre and post-harvest of catches such as net mending, sorting of fishes upon landing, fish retail selling, trading, auctioning fishes in the market, processing and preserving the unsold catches by salting, pickling or drying. It has been observed that men are involved in marketing activities mainly while dealing with intermediaries when the fish catch is of high commercial value. Otherwise women handled the small scale marketing that involved inexpensive fish varieties. Fish processing and preservation is mainly the arena of women because fishermen go to the deep sea during odd hours and return. Women assist in carrying the nets during early hours when they leave to the sea and return home. When men returned from the sea with the catch they took over the 
responsibility in unloading the fishes from the boats and segregating the fishes as per their sizes and categories. Then they transported the fishes to the auction center. The senior women who had experience involved in the auctioning of the fishes. The retailer fishers who offered the best price will be given the catches. Both men and women were seen sharing the work. While the men went to the sea to catch fishes, the women completed their household work and ensured that the catches were made use properly. There were some fisherwomen who even ventured into the lake through night and caught shrimps and crabs in shallow waters. They had to encounter several dangerous snakes, insects and other creatures sting when they had to remain calm to catch the prawns. Their hands had scars of stings from prawns and crabs.

Despite working for longer hours the fishers get only on an average Rs. 200/- to Rs. 400/- each day which included the labor of both men and women equally. The hard labor of fishers was exploited by middlemen and commission agents who indulged in getting commissions from fishers and the whole sale and retail fish buyers. They swindled commission from the fishers by exploiting their ignorance, poverty and illiteracy. Therefore it is the need of the hour that the government takes stringent measures against the middlemen who charged commissions from the fishers and provide space as requested by the fishers to involve in direct sales. The fishers should be allowed to fix their own price based on their catches and yield.

During the off season and the breeding period when the fishers are prohibited from venturing into sea, the Tamil Nadu Fisheries department remits Rs. 5000/- to each fisherman family as compensation. The 61 days ban on fishing is aimed at protecting the finger lings. It also helps in rejuvenating the marine resources. This ban period is effective from April 15 to June 14 on the East Coast every year. On the West Coast it is effective from June 1 to July 31. Although, the government gives compensation during the ban period, it is not sufficient for the poor fisher families. During such situations the fisherwomen seek informal credits from relatives and neighbors to manage their basic needs.

The banks and other formal credit institutions recognize men as borrowers but women financially support their families by borrowing through informal community links. They tend to do all kinds of jobs like cattle rearing, farming, poultry rearing, selling of dairy products assisting in grocery shops, making palm leaf products as self-help groups. It is clear from the study that the post-harvest activities, such as fish marketing and processing which women have assumed, depends only on the catches. It required capital which the poor fishing households could not afford. Their plea is that the government should provide free training and technical assistance to the fishers in aquaculture, storage facilities and seed production. They expressed that they will be able to learn the skills in a better manner.

Another major problem the fishers faced was the silting of the river mouths which leads to its closure was considered detrimental to the fishers as it affected the catch negatively. It is suggested that the Tamil Nadu government should desilt the lake which is causing much unrest amongst the fisher communities. Besides, certain unscientific practices are practiced proving to be problematic to the environment and ecosystem making themselves vulnerable again. The industrial pollution from the Arani and Kalangi rivers carried fertilizers, petrochemical waste and pesticides which is affecting the lagoon. Moreover, crab culture ponds and fish processing industries discharge a lot of effluents into the lake. Toxic fly ash and hot water from the North Chennai Thermal Power Station is also a major source of pollution concern. Two harbors Kamarajar Port and Larson \& Toubro's (L\&T) Kattupalli Port have propped up along the coast. The shipyards have also made the mangroves scanty.

\section{Acknowledgement}

The researcher would like to acknowledge the financial assistance received from the the University Grants Commission to undertak the Minor Research Project during 2018-2020. The research would like to thank the Principal of Madras Christian College, Staff and students of the Department of Public Administration for their support in completion of the research project. A special thanks to all the volunteers who were responsible in completing the project.

\section{References}

Amita Saxena, (2011). Fisheries Economics, pp:62-63, Daya Publishing House, New Delhi: Astral International Pvt. Ltd.

Coulthard, S., (2006). Developing a people centered approach to the coastal management of Pulicat lake a threatened coastal wetland in South India. PhD Thesis, Department of Economics and International Development, University pdf Bath, United Kingdom.

Fisheries at a Glance (2016-17). http://www.fisheries.tn.gov

https://timesofindia.indiatimes.com/city/chennai/fishing-ban-compensation-tamil-nadu-govt-deposits-rs-83-5-crore-infishermens-bank-accounts/articleshow/69814438.cms 
Mathew, (1991). Study of territorial use rights in small scale fisheries. Traditional systems of fishery management in Pulicat lake, Tamil Nadu, India, Food and Agriculture Organization, Fisheries Circular, p. 839.

Nagarjuna, A., Nandakumar, N.V., Kalarani, V. and Reddy, D.C. (2010). Aquatic and avian biodiversity of Pulicat brackish water lake and ecological degradation. World Journal of Fish and Marine Sciences. 2(2). 118-123.

Nanda Kumar, N.V. (2000). Impact of brackish water aquaculture effluent on coastal wetland ecology on avifauna of Pulicat lake. Technical report submitted to the World Bank through Department of Forest, Government of Andhra Pradesh.

Sanjeeva Raj, P.J. (2006). Macro Fauna of Pulicat Lake, National Biodiversity Authority, Chennai, Tamil Nadu, India, pp. 63-65.

Shanti, B. et al. (2012). Successful Women Entrepreneurs in Aquaculture Sectors-Case Studies of Tamil Nadu, Asian Fisheries Science Special Issue.

Vijaya, Khader, (2008). Empowerment of Fisher Women-in CCoastal Ecosystem of Andhra Pradesh, Karnataka, Kerala and Tamil Nadu, Agrotech Publishing Academy, Udaipur, p. 25.

Cite this article as: B. Madhana Rekha (2021). Economic contributions of fisherwomen in Pulicat lakefor public policy considerations. International Journal of Political Science and Public A dministration. 1(1), 31-35. doi: 10.51483/ IJPSPA .1.1.2021.31-35. 